\title{
Analisis Pembuktian Terbalik Kasus Tindak Pidana Korupsi Dalam Perspektif HAM
}

\author{
Hasuri, $^{1}$ Mia Mukaromah ${ }^{2}$ \\ Universitas Serang Raya Banten \\ https://doi.org/10.32507/mizan.v4i2.820
}

\begin{abstract}
Corruption is considered an extraordinary crime and requires extraordinary handling as well. In handling corruption, special handling is needed by using the theory of inverse evidence or reversing the burden of proof, but in a balanced way. This is in order to avoid the potential to violate human rights principles and respect the rights of the accused. The method used is an empirical normative legal research method, which is a combination of normative legal provisions (laws) with empirical elements (legal events in the community or social elements).

Keywords: Reverse Proof, Corruption, Human Rights
\end{abstract}

\begin{abstract}
Abstrak
Tindak pidana korupsi dianggap sebagai kejahatan yang luar biasa (extraordinary crime) dan memerlukan penanganan yang luar biasa pula. Dalam penanganan tindak pidana korupsi diperlukan penanganan yang khusus dengan menggunakan teori pembuktian terbalik atau pembalikan beban pembuktian namun secara berimbang. Hal tersebut agar terhindar dari potensi melanggar prinsip HAM dan penghargaan hak-hak terdakwa. Metode yang digunakan adalah metode penelitian hukum normatif empiris yaitu penggabungan dari ketentuan hukum normatif (undang-undang) dengan unsur-unsur empiris (peristiwa hukum di masyarakat atau unsur sosial).
\end{abstract}

Kata Kunci: Pembuktian Terbalik, Tindak Pidana Korupsi, Hak Asasi Manusia

* Naskah diterima tanggal: 17 September 2020, direvisi: 15 Oktober 2020, disetujui untuk terbit: 10 Desember 2020.

${ }^{1}$ Hasuri adalah Dosen pada Universitas Serang Raya Banten. Email: majalah.assaadah@gmail.com.

${ }^{2}$ Mia Mukaromah adalah Peneliti pada Universitas Serang Raya Banten. Email: falsafamaitreya@gmail.com. 


\section{A. PENDAHULUAN}

Pancasila dan UUD 1945 menjadi fundamental negara Indonesia dalam melakukan pembangunan nasional untuk mewujudkan masyarakat Indonesia yang adil, makmur, dan sejahtera. Usaha yang konsisten perlu terus ditingkatkan agar citacita bangsa dapat tercapai. Salah satunya adalah usaha pencegahan dan pemberantasan tindak pidana korupsi. Sekertaris jendral PBB Kofi Annan menyebutkan dalam kata pengantarnya pada Konvensi PBB mengenai Antikorupsi (United Nation Convention Against Corruption, 2003) bahwa korupsi menjadi wabah yang sangat berbahaya memiliki begitu banyak efek merusak terhadap masyarakat. Korupsi dapat melemahkan demokrasi dan supremasi hukum (the rule of law), menyebabkan terjadinya pelanggaran HAM, mengacaukan pasar, mengikis kualitas hidup dan membiarkan tumbuh subur kejahatan terorganisasi dan ancaman-ancaman lain terhadap keamanan umat manusia.

Indonesia salah satu negara berkembang mengalami kondisi yang cukup parah karena sebagian besar provinsi di Indonesia yang dipimpin kepala daerah tersangkut masalah hukum. dari 32 gubernur, 17 diantaranya tersangkut perkara sehingga harus dinonaktifkan dari jabatan ${ }^{3}$. Berdasarkan data dari Kementrian Dalam Negeri sejak tahun 2004 hinggal Februari 2013, sedikitnya 291 kepala daerah baik tingkat provinsi maupun kabupaten/kota terlibat kasus korupsi. Jumlah tersebut terdiri dari gubernur sebanyak 21 orang, wakil gubernur 7 orang, bupati 156 orang, wakil bupati 46 orang, walikota 41 orang, dan wakil walikota 20 orang. Karena hal tersebut tidak mengherankan jika survei internasional yang diselenggarakan oleh badan Konsultasi Risiko Politik dan Ekonomi (PERC) Hong Kong pada 2004, telah menyebutkan Indonesia sebagai negara terkorup kedua di Asia setelah Vietnam. Bahkan pada tahun 2010 PERC menempatkan Indonesia pada posisi pertama sebagai negara terkorup dengan cetak skor 9,07 dari nilai 10 .

Dari paparan di atas dapat disimpulkan bahwa tindak pidana korupsi tidak mengalami penurunan bahkan cenderung meningkat, meskipun berbagai upaya telah dilakukan untuk mengatasinya. Berkaitan dengan hal tersebut pada rapat paripurna DPR RI mengenai Rancangan Undang-Undang RI perubahan atas Undang-Undang No. 31 Tahun 1999 Tentang Pemberantasan Tindak Pidana Korupsi menjadi UndangUndang Nomor 20 Tahun 2001 pada tanggal 21 mei 2001 pemerintah menjelaskan pokok-pokok pikiran berkaitan dengan pemberantasan, diantaranya:

Pertama, untuk lebih meningkatkan upaya pemberantasan tindak pidana korupsi yang telah menimbulkan kerugian negara atau perekonomian negara dan masyarakat pada umumnya sesuai dengan tuntutan hati nurani rakyat, maka diperlukan landasan hukum yang kuat, yang mampu menjamin terwujudnya penegakan supermasi hukum dan hak asasi manusia berdasarkan keadilan, kebenaran dan kepastian hukum.

Kedua, tindak pidana korupsi yang selama ini terjadi secara sistematik dan meluas, tidak hanya merugikan keuangan negara, tetapi juga telah merupakan

\footnotetext{
${ }^{3}$ Mansur Kartayasa, Korupsi Dan Pembuktian Terbalik Dari Perspektif Kebijakan Legislasi Dan Hak Asasi Manusia (Jakarta: Kencana, 2017).
} 
pelanggaran terhadap hak-hak sosial dan ekonomi masyarakat secara luas. Oleh karena itu tindak pidana korupsi, perlu digolongkan sebagai kejahatan yang pemberantasannya harus dilakukan secara luar biasa. Dengan demikian, pemberantasan tindak pidana korupsi harus dilakukan dengan cara yang khusus, antara lain dengan penerapan sistem pembuktian terbalik yakni pembuktian yang dibebankan terhadap terdakwa. Artinya, terdakwa sudah dianggap terbukti melakukan tindak pidana korupsi, seperti pegawai negeri yang menerima hadiah Rp. 10.000.000,- (sepuluh juta rupiah) atau lebih telah dianggap terbukti menerima suap, kecuali yang bersangkutan mampu membuktikan sebaliknya. Tetapi, penerima hadiah yang dibawah Rp. 10.000.000,- (sepuluh juta rupiah), penyidikan dan penuntutannya berlaku sistem pembuktian biasa, yaitu jaksa yang harus membuktikan kesalahan terdakwa. Dengan kata lain jaksa yang membuktikan dilakukan atau tidaknya suatu tindak pidana korupsi oleh seseorang.

Cara-cara luar biasa atau khusus dalam pemberantasan tindak pidana korupsi dengan melakukan pembuktian terbalik yang menyebabkan beralihnya beban pembuktian dari tangan jaksa penuntut umum kepada tersangka atau terdakwa untuk membuktikan bahwa dirinya terbukti tidak bersalah. Apakah ketentuan tersebut bertentangan dengan kewajiban jaksa penuntut umum sebagai pihak yang mengajukan perkara untuk membuktikan perbuatan dan kesalahan yang dilakukan terdakwa, disamping itu hal tersebut tidak sesuai dengan asas praduga tak bersalah (presumption of innocent) dan asas tidak mempersalahkan diri sendiri (non self incrimination) yang merupakan perwujudan dari hak asasi manusia.

Secara etimologis, Fockema Andreae sebagaimana yang dikutip Andi Hamzah mengemukakan bahwa kata korupsi berasal dari bahasa latin corruption atau corruptus yang berasal dari kata corrumpere kemudian diadopsi oleh ke banyak bahasa seperti Inggris, corruption, corrupt, Perancis corruption. Belanda corruptie (korruptie) yang kemudian diadopsi dalam bahasa Indonesia menjadi korupsi. Dalam kamus umum bahasa Inggris-Indonesia karangan S. Wojo Wasito, WJS. Poerwadarminta, SAM. Gaastra, JC. Tan (Mich) arti istilah corrupt ialah busuk atau buruk.

Dalam bahasa Indonesia istilah korupsi ialah perbuatan yang buruk seperti penggelapan uang, penerimaan uang sogok dan sebagainya. Di Malaysia istilah korupsi dikenal dengan istilah resuah yang berasal dari bahasa Arab (riswah) yang merupakan perbuatan yang buruk. Perbuatan korupsi sebagai perbuatan pidana khusus yang dikategorikan sebagai kejahatan luar biasa (extraordinary crime) yang dalam penanganannya membutuhkan cara yang khusus. Untuk mengenal berbagai bentuk dan jenis tindak pidana korupsi perlu dipahami melalui peraturan perundang-undangan yang berkaitan dengan perbuatan tindak pidana korupsi, misalnya pada ketentuan lama peraturan Pemerintah Pengganti Undang-Undang (PERPU) No. 24 Tahun 1960 tentang Pengusutan, Penuntutan dan Pemeriksaan tindak pidana korupsi, mengenal tipologi tindak pidana korupsi sebagai berikut:

1. Tindakan seseorang yang dengan atau karena melakukan suatu kejahatan atau pelanggaran memperkaya diri sendiri atau orang lain atau suatu badan yang secara langsung atau tidak langsung merugikan keuangan atau perekonomian 
negara atau daerah atau merugikan keuangan suatu badan yang menerima bantuan dari keuangan negara atau daerah atau badan hukum lain yang menggunakan modal dan kelonggaran-kelonggaran dari negara atau masyarakat.

2. Perbuatan seseorang yang dengan atau karena melakukan suatu kejahatan atau pelanggaran memperkaya diri sendiri atau orang lain atau badan dan yang dilakukan dengan menyalahgunakan jabatan atau kedudukan.

3. Kejahatan-kejahatan yang tercantum dalam Pasal 17 sampai 21 peraturan ini dan dalam Pasal 209,201,415,416,417,418,419,420,423,425 dan 435 Kitab UndangUndang Hukum Pidana.

Selain itu tipologi tindak pidana korupsi secara yuridis juga tercantum dalam Undang-Undang Nomor 3 Tahun 1971 (LN No. 17 TLN No. 2928) dan Undang-Undang Nomor 31 Tahun 1999. Undang-Undang Nomor 20 Tahun 2001 Tentang Pemberantasan Tindak Pidana Korupsi. Tindak pidana korupsi juga dapat dikatakan sebagai pelanggaran HAM karena tindakan tersebut telah merampas hak-hak masyarakat, baik sosial, ekonomi dan budaya.

HAM adalah hak-hak yang bersifat mendasar dan melekat dengan jati diri manusia secara universal. ${ }^{4}$ Hak asasi manusia merupakan hak yang secara hakiki dimiliki oleh manusia karena martabatnya sebagai manusia yang dimilikinya sejak lahir. Pada dasarnya, hak asasi manusia itu merupakan hak yang inherent dimiliki oleh setiap manusia sebagai makhluk Tuhan. Dengan begitu hak asasi manusia dimiliki oleh siapapun, tidak terkecuali oleh anak. Bahkan di dalam terminologi hukum perdata, hak keperdataan seseorang itu telah diakui semenjak ia masih berada dalam kandungan.

Mendasarkan pada pemikiran bahwa hak asasi manusia merupakan hak kodrati yang melekat dan tidak dapat dipisahkan dari manusia itu sendiri, berarti juga meliputi jaminan perlindungan atas hak-hak yang tidak dapat dikurangi dalam situasi apapun (non-derogable rights), yakni hak untuk hidup, hak untuk tidak disiksa, hak persamaan dihadapan hukum (equality before the law) dan lain sebagainya.

Dalam konteks Indonesia, pengakuan dan penghormatan terhadap hak-hak asasi manusia yang demikian itu tidak lain merupakan konsekuensi dari corak negara hukum yang dianut oleh Indonesia. Pasal 1 ayat (3) UUD 1945 telah menggariskan bahwa negara Indonesia adalah negara hukum. Dalam penjelasannya dengan tegas disebutkan bahwa, "Negara Indonesia berdasar atas hukum (rechstaat) tidak atas kekuasaan belaka (machtstaat)." Ketentuan tersebut, mengandung arti bahwa segala tindakan pemerintahan harus didasarkan atas hukum.

\section{B. METODE PENELITIAN}

Metode penelitian yang digunakan dalam penelitian ini adalah dengan metode penelitian hukum normatif empiris. Metode penelitian normatif empiris merupakan

\footnotetext{
${ }^{4}$ Majda Muhtaj El, Hak Asasi Manusia Dalam Konstitusi Indonesia (Jakarta: Kencana, 2004).
} 
penelitian melihat dari hukum yang bekerja pada segi kaidah dan norma berupa peraturan perundang-undangan yang berkaitan dengan tindak pidana korupsi dan dengan tidak terlepas dari unsur sosial/empiris yakni kenyataan yang ada di masyarakat adanya pemahaman terkait pembuktian terbalik dalam tindak pidana korupsi.

Teknik dalam pengumpulan data dengan cara studi pustaka yaitu teknik pengumpulan dan informasi dengan menelaah sumber-sumber tertulis yang relevan dan berhubungan dengan objek yang sedang diteliti sehingga mampu menjawab permasalahan yang dihadapi. Analisis data dilakukan secara kualitatif yaitu dengan menelaah seluruh data yang tersedia kemudian dilakukan reduksi data sehingga menghasilkan penafsiran data yang sesuai dengan tujuan penelitian.

\section{ANALISIS DAN PEMBAHASAN}

\section{Pengertian Pembuktian}

Pembuktian merupakan kegiatan membuktikan suatu peristiwa untuk menunjukkan benar atau tidaknya seorang terdakwa dalam persidangan. Dalam pengkajian secara yuridis, menurut M. Yahya Harahap, pembuktian merupakan ketentuan-ketentuan yang berisi penggarisan dan pedoman tentang cara-cara yang dibenarkan undang-undang membuktikan kesalahan yang didakwakan kepada terdakwa. Pembuktian pula mengatur alat-alat bukti yang dibenarkan undang-undang dan mengatur mengenai alat bukti yang boleh digunakan hakim guna membuktikan kesalahan terdakwa. Dalam pembuktian perkara pidana dikenal beberapa teori sistem pembuktian, yaitu:

a. Sistem pembuktian menurut undang-undang secara positif (posistief wettelijke bewijs theorie)

Menurut teori ini, sistem pembuktian positif bergantung pada alat-alat bukti sebagaimana disebut secara limitative dalam undang-undang. Undang-undang telah menentukan tentang alat bukti yang boleh dipakai oleh hakim, bagaimana alat bukti tersebut digunakan. Kekuatan alat bukti tersebut dan bagaimana cara hakim harus memutus terbukti atau tidaknya perkara yang sedang diadili. Dalam hal ini berarti hakim terikat kepada undang-undang. Hakim harus menyatakan terdakwa bersalah jika alat-alat bukti yang digunakan membuktikan terdakwa bersalah walau hakim berkeyakinan bahwa sebenarnya terdakwa tidak bersalah. Begitupun sebaliknya, hakim harus rela menyatakan terdakwa tidak bersalah jika alat-alat bukti yang digunakan tidak membuktikan bersalah, walau hakim berkeyakinan bahwa terdakwa bersalah.

b. Sistem pembuktian menurut keyakinan hakim (conviction intimel conviction raisonee)

Merupakan teori pembuktian berdasarkan keyakinan hakim, hakim dapat menjatuhkan keputusannya berdasarkan keyakinan belaka dan tidak terikat oleh suatu peraturan. Pada sistem pembuktian ini keyakinan hakim memegang 
peranan penting untuk menentukan kesalahan terdakwa, namun keyakinan hakim tersebut harus dilakukan secara selektif dalam artian hakim dibatasi dengan harus didukung oleh alasan-alasan jelas dan rasional dalam mengambil keputusan, tidak semata-mata atas dasar keyakinan yang tertutup tanpa uraian alasan yang masuk akal.

c. Sistem pembuktian menurut undang-undang secara negatif (negatif wettelijke bewijs theorie)

Teori ini memiliki prinsip bahwa sistem pembuktian menurut undang-undang secara negative menentukan bahwa hakim hanya boleh menjatuhkan pidana terhadap terdakwa apabila alat bukti tersebut secara limitatif ditentukan oleh undang-undang 5 , dan didukung oleh adanya keyakinan hakim terhadap eksistensi alat-alat bukti tersebut. Dalam menentukan salah atau tidaknya seorang terdakwa menurut sistem pembuktian undang-undang secara negatif, terdapat dua komponen, yaitu pembuktian harus dilakukan menurut cara dan dengan alat-alat bukti yang sah menurut undang-undang dan keyakinan hakim yang juga harus didasarkan atas cara dengan alat-alat bukti yang sah menurut undang-undang

Dengan demikian, sistem ini memadukan unsur objektif dan subjektif dalam menentukan salah atau tidaknya terdakwa. Tidak ada yang dominan diantara unsur tersebut. Keduanya saling melengkapi dan mendukung dalam membuktikan kesalahan terdakwa. Jika salah satu unsur tidak terpenuhi maka terdakwa belum bisa dinyatakan bersalah.

Dalam pembuktian menurut hukum acara pidana Indonesia dalam membuktikan kesalahan terdakwa minimum terdapat dua alat bukti sebagaimana disebutkan dalam Pasal 183 KUHAP yaitu "hakim tidak boleh menjatuhkan pidana kepada seseorang kecuali apabila dengan sekurang-kurangnya dua alat bukti yang sah ia memperoleh keyakinan bahwa suatu tindak pidana benar-benar terjadi dan bahwa terdakwalah yang bersalah melakukannya." Secara limitatif bukti yang disebutkan dalam Pasal 183 KUHAP yaitu a). Keterangan saksi, b). Keterangan ahli, c). Surat, d). Petunjuk, e). Keterangan terdakwa. Bagi hakim, sekurang-kurangnya dua alat bukti sah yang telah ditetapkan oleh undang-undang dapat dijadikan sumber keyakinan hakim dalam menentukan kesalahan terdakwa.

\section{Pembuktian Terbalik Pada Kasus Tindak Pidana Korupsi Dalam Perspektif Hak Asasi Manusia}

Dalam ketentuan hukum acara pidana secara umum mengatur bahwa beban pembuktian dalam perkara tindak pidana umum diserahkan kepada jaksa penuntut, sedangkan tindak pidana korupsi sebagai tindak pidana khusus memiliki sifat pengecualian juga memiliki sifat khusus, baik yang berkaitan dengan hakim pidana

\footnotetext{
${ }^{5}$ Yahya. Harahap, Pembahasan Permasalahan Dan Penerapan KUHAP (Jakarta: Sinar Grafika, 2009).
} 
materiil maupun formil. Hal itu didasarkan pada ketentuan Pasal 63 Ayat (2) KUHP yaitu "apabila untuk suatu perbuatan yang telah diatur dalam suatu ketentuan pidana yang bersifat umum diatur pula oleh suatu ketentuan pidana yang bersifat khusus, maka ketentuan pidana khusus inilah yang harus diberlakukan." Asasnya adalah lex specialis derogate legi generali.

Andi Hamzah menganjurkan istilah yang digunakan adalah perundangundangan pidana umum dan perundang-undangan pidana khusus ${ }^{6}$. Yang dimaksud dengan perundang-undangan pidana umum adalah KUHP beserta semua perundangundangan yang mengubah dan menambah KUHP. Adapun perundang-undangan pidana khusus ialah semua perundang-undangan di luar KUHP beserta perundangundangan pelengkapnya, baik perundang-undangan pidana maupun yang bukan pidana tetapi bersanksi pidana.

Undang-Undang Nomor 20 Tahun 2001 hasil pembaharuan dari UndangUndang Nomor 31 Tahun 1999 Tentang Pemberantasan Tindak Pidana Korupsi merupakan jenis Tindak Pidana Khusus baik dilihat dari sudut pandang logis maupun sudut pandang yuridis atau sistematis. Tentang pembuktian penjelasan UndangUndang Nomor 31 Tahun 1999 menyebutkan undnag-undang ini juga menerapkan pembuktian terbalik yang bersifat terbatas atau berimbang. Yaitu terdakwa mempunyai hak untuk membuktikan bahwa ia tidak melakukan tindak pidana korupsi dan wajib memberikan keterangan tentang seluruh harta benda setiap orang atau korporasi yang diduga mempunyai hubungan dengan perkara yang bersangkutan, dan penuntut umum tetap berkewajiban membuktikan dakwaannya.

Tentang pembalikan beban pembuktian, Undang-Undang Nomor 20 Tahun 2001 juga telah memperluas dalam penjelasan yang menyebutkan pembuktian terbalik ini diberlakukan juga pada tindak pidana baru tentang gratifikasi dan terhadap tuntutan perampasan harta benda terdakwa yang diduga dari salah satu tindak pidana. Ketentuan tersebut membuktikan bahwa Undang-Undang Tindak Pidana Korupsi merupakan hukum pidana yang bersifat khusus sehingga asas lex specialis derogate legi generali harus diberlakukan.

Pembuktian terbalik merupakan sistem dimana beban pembuktian berada pada terdakwa dan proses pembuktian ini hanya berlaku pada saat pemeriksaan di sidang pengadilan dengan dimungkinkannya dilakukan pemeriksaan tambahan atau khusus jika dalam pemeriksaan persidangan diketemukan harta benda milik terdakwa yang diduga berasal dari tindak pidana korupsi namun hal tersebut belum didakwakan. Ketentuan tentang pembuktian terbalik atau pembalikan beban pembuktian tindak pidana korupsi dalam Undang-Undang Nomor 31 Tahun 1999 Tentang Pemberantasan Tindak Pidana Korupsi yang telah diperbaharui dengan Undang-Undang Nomor 20 Tahun 2001 Tentang Pemberantasan Tindak Pidana Korupsi maupun dalam UndangUndang Nomor 3 Tahun 1971 yang ditunjukan terhadap perbuatan kesalahan pelaku (Pasal 37) merupakan pergeseran (shifting) beban pembuktian atau "shifting of burden proof" bukan "reversal of burden proof" (pembalikan beban pembuktian) secara murni.

${ }^{6}$ Andi Hamzah, Asas-Asas Hukum Pidana (Bandung: Rineka Cipta, 2008). 
Hal tersebut dikarenakan terdakwa dapat membuktikan dirinya tidak bersalah atau tidak melakukan tindak pidana korupsi setelah diperkenankan oleh hakim. Selain itu, pembuktian bahwa terdakwa tidak melakukan tindak pidana korupsi tidak bersifat imperatif, karena merupakan hak terdakwa. Maksudnya, apabila terdakwa tidak menggunakan kesempatan ini maka hal tersebut justru akan merugikan dirinya sendiri dan dapat memperkuat dugaan penuntut umum bahwa terdakwa memang benar telah melakukan tindak pidana korupsi. Sebaliknya, jika terdakwa dapat membuktikan bahwa ia tidak melakukan tindak pidana korupsi, maka hal tersebut akan menguntungkan bagi terdakwa. Dalam keadaan ini, jaksa penuntut umum tetap wajib membuktikan bahwa terdakwa bersalah melakukan tindak pidana korupsi, dengan demikian beban pembuktian diserahkan kepada keduanya, jaksa penuntut umum maupun terdakwa.

Jadi dalam teori pembuktian terbalik atau pembalikan beban pembuktian yang dianut oleh Indonesia bukan teori murni atau absolut melainkan hanya merupakan pergeseran beban pembuktian atau "shifting of burden proof". Hal ini disebabkan karena teori pembuktian terbalik secara murni atau absolut akan bersinggungan dengan HAM khususnya implementasi terhadap ketentuan hukum acara pidana. Perlu ditegaskan bahwa dalam shifting of burden proof yang terjadi adalah pergeseran saja bukan pembalikan beban pembuktian, sehingga yang istilah populer pada Undang-Undang Nomor 31 Tahun 1999 tentang Pemberantasan Tindak Pidana Korupsi dikenal dengan Sistem Pembalikan Beban Pembuktian Yang Terbatas atau berimbang.

Teori beban pembuktian berimbang dalam hukum positif Indonesia yang mengatur pemberantasan tindak pidana korupsi merupakan suatu conditio sine quanon, mengingat tindak pidana korupsi sudah menjadi tindak pidana yang bersifat luar biasa sehingga harus dihadapi secara luar biasa pula. Sistem pembuktian dalam proses perkara tindak pidana korupsi yang dianut suatu negara pula akan berpengaruh terhadap keberhasilan pemberantasan korupsi di negara bersangkutan. Apabila sistem yang dianut masih menggunakan sistem pembuktian dengan beban pembuktian berada dipihak penuntut umum sepenuhnya yang didasarkan pada presumption of innocence secara mutlak, upaya pemberantasan tindak pidana korupsi yang dilakukan tidak akan mencapai hasil yang maksimal.

\section{KESIMPULAN}

Pembuktian adalah salah satu cara untuk meyakinkan hakim agar ia dapat memutuskan suatu perkara yang menentukan terdakwa itu bersalah atau tidak. Pembuktian merupakan hal yang sangat penting dalam proses persidangan. Hal yang pokok dalam pembuktian adalah alat-alat bukti. Dalam menentukan suatu perkara sedikitnya harus ada dua alat bukti yang sah yang telah ditetapkan oleh undangundang.

Teori pembuktian terbalik atau pembalikan beban pembuktian pada kasus tindak pidana korupsi di Indonesia tidak menganut secara mutlak melainkan hanya sebagai pergeseran yang dikenal dengan istilah teori pembuktian berimbang. Dengan 
teori pembuktian berimbang maka pembuktian bukan saja dibebankan pada terdakwa melainkan pada jaksa penuntut umum pun harus dapat membuktikan bahwa terdakwa bersalah. Dengan itu, ketentuan teori pembuktian berimbang tidak melanggar prinsip Hak Asasi Manusia (HAM) dan penghargaan hak-hak terdakwa dalam asas umum hukum pidana yang menyatakan siapa yang menuntut, dialah yang harus membuktikan kebenaran tuntutannya.

\section{REFERENSI}

El, Majda Muhtaj, Hak Asasi Manusia Dalam Konstitusi Indonesia (Jakarta: Kencana, 2004)

Hamzah, Andi, Asas-Asas Hukum Pidana (Bandung: Rineka Cipta, 2008)

Harahap, Yahya., Pembahasan Permasalahan Dan Penerapak KUHAP (Jakarta: Sinar Grafika, 2009)

Kartayasa, Mansur, Korupsi Dan Pembuktian Terbalik Dari Perspektif Kebijakan Legislasi Dan Hak Asasi Manusia (Jakarta: Kencana, 2017)

\section{UNDANG-UNDANG}

Undang-Undang Nomor 39 Tahun 1999 Tentang Hak Asasi Manusia

Undang-Undang Nomor 20 Tahun 2001 Tentang Pemberantasan Tindak Pidana Korupsi. 
Hasuri, Mia Mukaromah 